\title{
Maya Index dan Kepadatan Larva Aedes aegypti di Kota Ternate, Maluku Utara
}

\section{Maya Index and Density of Aedes aegypti Larvae in Ternate City, North Maluku}

\author{
Amalan Tomia ${ }^{1 *}$, Upik Kesumawati Hadi $^{2}$, Susi Soviana ${ }^{2}$, Elok Budi Retnani ${ }^{2}$ \\ ${ }^{1}$ Universitas Muhammadiyah Maluku Utara \\ Jalan KH. Ahmad Dahlan No.100, Kelurahan Sasa, Kecamatan Ternate Selatan, Kota Ternate, \\ Indonesia \\ ${ }^{2}$ Parasitologi dan Entomologi Kesehatan, Fakultas Kedokteran Hewan - Institut Pertanian Bogor \\ Jalan Agatis Kampus IPB Darmaga, Bogor, Jawa Barat, Indonesia \\ E_mail:alga_tte@yahoo.co.id
}

Received date: 28-06-2019, Revised date: 29-09-2019, Accepted date: 11-10-2019

\begin{abstract}
Abstrak
Demam Berdarah Dengue (DBD) adalah penyakit menular yang disebabkan oleh virus Dengue dan ditularkan melalui gigitan nyamuk Aedes aegypti. Pengetahuan terkait habitat larva sangat penting untuk pengendalian $A e$. aegypti. Penelitian ini bertujuan untuk menghitung kepadatan larva Ae. aegypti dan maya indeks di Kota Ternate. Koleksi larva Aedes spp. menggunakan metode single larva. Pengamatan karakteristik habitat dilakukan secara visual dengan mengamati kontainer yang menjadi habitat larva Ae. aegypti. Penelitian dilakukan pada 20 kelurahan di Kota Ternate selama 5 bulan. Parameter yang dihitung adalah Container Index (CI), Breteau Index (BI), House Index (HI), Density Figure (DF), dan maya index. Berdasarkan maya index, sebanyak 1.990 rumah pada 20 kelurahan di Kota Ternate termasuk dalam kategori risiko sedang $(78,64 \%)$ dengan nilai CI (43,95\%), HI (84,99\%), BI $(228,91)$, dan DF pada kategori tinggi (DF=8,7). Dapat disimpulkan bahwa sebagian besar rumah penderita masih memiliki potensi penularan infeksi virus Dengue.
\end{abstract}

Kata kunci: maya index, Aedes aegypti, Kota Ternate

\begin{abstract}
Dengue hemorrhagic fever $(D H F)$ is a contagious disease caused by the dengue virus and transmitted through the bite of Aedes aegypti. Information regarding larval habitat is very important for the control of Ae. aegypti. The studied aims to determine the density of Ae. aegypti larvae and maya index in Ternate City. The research conducted in 20 urban villages in Ternate City for 5 months. Survey method used was single larva and any water reservoirs were found larvae of Aedes spp. will be taken as a sample. The purpose of this study to measure the density of Ae. aegypti larvae and maya index in Ternate City. The parameters calculated were Container Index (CI), Breteau Index (BI), House Index (HI), Density Figure (DF), and Maya Index. Based on maya index, 1.990 houses in 20 urban villages in Ternate City included in the medium risk category (78.64\%) with CI (43.95\%), HI (84.99\%) and BI (228.91). Density figure in the high category (DF = 8.7). The study concluded that most of households in the area of study still have the potential for transmission of dengue virus infection.
\end{abstract}

Keywords: maya index, Aedes aegypti, Ternate City

\section{PENDAHULUAN}

Demam Berdarah Dengue (DBD) merupakan masalah penting di Indonesia, seiring dengan meningkatnya mobilitas dan kepadatan penduduk, jumlah penderita serta bertambah luasnya penyebaran DBD. Jumlah penderita DBD di Indonesia pada tahun 2014 dan 2015 sebesar 100.347 dan 126.675 kasus DBD. ${ }^{1}$ Kasus DBD telah ditemukan pada hampir semua kabupaten/kota di Provinsi Maluku Utara. Laporan Dinas Kesehatan Kota Ternate tahun 2017 menunjukkan bahwa terdapat 37 kasus DBD di Propinsi Maluku Utara dan 20 kasus DBD di antaranya terdapat di Kota Ternate. ${ }^{2}$

Demam Berdarah Dengue merupakan penyakit berbasis lingkungan dengan nyamuk Aedes aegypti sebagai vektornya. Azlina et al. menjelaskan bahwa penyakit DBD merupakan salah satu penyakit yang berbasis lingkungan yang perkembangannya dipengaruhi oleh faktor lingkungan. ${ }^{3}$ Kondisi lingkungan pemukiman yang buruk sangat mempengaruhi perkembangan nyamuk Ae. aegypti. 
Aedes aegypti mempunyai habitat perkembangbiakan di tempat penampungan air atau wadah dengan air yang relatif jernih, baik di dalam atau luar rumah serta tempat-tempat umum. ${ }^{4}$

Habitat perkembangbiakan nyamuk Ae. aegypti menurut Kemenkes RI dapat dikelompokkan sebagai berikut: 1) Tempat Penampungan Air (TPA) untuk keperluan sehari-hari, seperti: drum, tangki reservoir, tempayan, bak mandi/wc, dan ember. 2) Tempat Penampungan Air bukan untuk keperluan sehari-hari seperti: tempat minum burung, vas bunga, perangkap semut, bak kontrol pembuangan air, tempat pembuangan air kulkas/dispenser, talang air yang tersumbat, barang-barang bekas (contoh : ban, kaleng, botol, plastik, dll). 3) Tempat Penampungan Air alamiah seperti: lubang pohon, lubang batu, pelepah daun, tempurung kelapa, pelepah pisang, dan potongan bambu dan tempurung coklat/karet, dll. ${ }^{4,5}$

Keberadaan kontainer sebagai habitat perkembangbiakan Ae. aegypti dapat meningkatan kepadatan populasi Ae. aegypti sehingga memicu tingginya risiko penularan virus dengue. ${ }^{6}$ Soedarto menjelaskan bahwa tingkat kepadatan larva Aedes spp. dilihat dari besaran parameter entomologis seperti House Index (HI), Container Index (CI), dan Breteau Index (BI) nilai tersebut dapat menginterpretasikan makna rasio penularan DBD. ${ }^{7}$ Semakin tinggi kepadatan nyamuk maka semakin tinggi pula risiko terinfeksi virus dengue. ${ }^{6}$ Hasil penelitian Sulistyorini et al. menunjukkan di daerah Baranangsiang mempunyai risiko penularan DBD pada tingkat sedang dan di daerah Bojongkerta mempunyai risiko penularan DBD pada tingkat tinggi berdasarkan kepadatan vektornya. $^{8}$

Penentuan tingkat risiko penularan DBD suatu wilayah biasanya dengan menggunakan maya index. Maya index dapat digunakan untuk mengidentifikasi sebuah lingkungan berisiko (tinggi, sedang atau rendah) sebagai tempat perkembangbiakan nyamuk. Maya index ditentukan berdasarkan tempat perkembangbiakan nyamuk Ae. aegypti yang didasarkan pada kebersihan lingkungan
Hygiene Risk Index (HRI) dan adanya tempat perkembangbiakan nyamuk Breeding Risk Index (BRI). ${ }^{9}$ Menurut Miller dalam Taslisia et al. bahwa indikator HRI dapat menggambarkan kebersihan rumah, semakin tinggi HRI berarti rumah semakin kotor atau tidak higienis. ${ }^{10}$ Breeding risk index menggambar ketersediaan tempat-tempat yang berpotensi sebagai habitat perkembangbiakan nyamuk, semakin tinggi BRI berarti semakin banyak kontainer yang berpotensi sebagai tempat perkembangbiakan nyamuk. Banyaknya tempat penampungan air di setiap rumah penduduk berpeluang menjadi tempat perkembangbiakan nyamuk Aedes sp. sebagai vektor virus dengue di masyarakat. Tujuan penelitian ini adalah untuk mengetahui kepadatan populasi larva Ae. aegypti dan maya index Kota Ternate.

\section{METODE}

\section{Lokasi dan Waktu Pengambilan Data}

Penelitian ini dilakukan di Kota Ternate Provinsi Maluku Utara. Penelitian dilaksanakan selama 5 bulan yaitu Oktober 2016 - Februari 2017.

Jenis penelitian ini merupakan observasional analitik dengan desain potong lintang (cross-sectional). Populasi adalah semua rumah yang ada di Kota Ternate yang tersebar di 20 kelurahan pada 4 kecamatan (Kecamatan Ternate Selatan, Kecamatan Ternate Tengah, Kecamatan Ternate Utara dan Kecamatan Pulau Ternate). Sampel yang diambil dengan cara simple random sampling dengan jumlah sampel 1.990 rumah. Penelitian ini hanya terbatas pada perumahan penduduk, yaitu rumah yang dijadikan sampel berdasarkan rumah yang pernah ada penderita DBD dan sekitar rumah dengan jarak maksimal 100 meter dari rumah penderita tersebut.

\section{Mengukur Kepadatan Larva Aedes spp.}

Pengukuran kepadatan larva menggunakan metode single larva yaitu pengambilan satu larva di setiap tempat penampungan air yang ditemukan larva untuk diidentifikasi untuk mengetahui jenis 
nyamuk. ${ }^{11}$ Cara Pengumpulan larva sebagai berikut : 1) Semua tempat atau bejana baik di dalam maupun di luar rumah yang dapat menjadi tempat perkembang biakan nyamuk Ae. aegypti diperiksa (secara visual) untuk mengetahui ada tidaknya jentik. 2) Untuk memeriksa jentik di tempat yang agak gelap atau airnya keruh digunakan senter selama 3 menit. 3) Data larva yang ditemukan di lapangan kemudian dihitung House Index (HI), Container Index (CI), dan Breteau Index (BI).

Kepadatan larva diukur berdasarkan rumus sebagai berikut:

$$
\begin{array}{lll}
\text { House Index }(\text { HI) } & =\frac{\text { jumlah rumah yang ditemukan jentik }}{\text { jumlah rumah yang diperiksa }} \times 100 \% \\
\text { Container Index }(\text { CI) } & =\frac{\text { Jumlah kontainer yang positif jentik }}{\text { Jumlah kontainer yang diperiksa }} \times \quad 100 \% \\
\text { Breteau Index }(\text { BI) } & =\frac{\text { Jumlah kontainer yang positif }}{\text { Jumlah rumah yang diperiksa }} \times \quad 100 \%
\end{array}
$$

Density Figure (DF) ditentukan setelah dibandingkan dengan tabel larva index (Tabel menghitung hasil HI. CI. BI kemudian 1) menurut Lestari et al. ${ }^{12}$

Tabel 1. Larva Index Aedes spp. di Kota Ternate Tahun 2017

\begin{tabular}{cccc}
\hline Density Figure $(\mathrm{DF})$ & House Index $(\mathrm{HI})$ & Container Index $(\mathrm{CI})$ & Breteau Index $(\mathrm{BI})$ \\
\hline 1 & $1-3$ & $1-2$ & $1-4$ \\
\hline 2 & $4-7$ & $3-5$ & $5-9$ \\
3 & $8-17$ & $6-9$ & $10-19$ \\
4 & $18-28$ & $10-14$ & $20-34$ \\
5 & $29-37$ & $15-20$ & $35-49$ \\
\hline 6 & $38-49$ & $21-27$ & $50-74$ \\
7 & $50-59$ & $28-31$ & $75-99$ \\
8 & $60-76$ & $32-40$ & $100-199$ \\
9 & $>77$ & $>41$ & $>200$ \\
\hline
\end{tabular}

Density figure dapat dikategorikan menjadi:

$$
\begin{aligned}
& \mathrm{DF}=1=\text { kepadatan rendah } \\
& \mathrm{DF}=2-5=\text { kepadatan sedang } \\
& \mathrm{DF}=6-9=\text { kepadatan tinggi }
\end{aligned}
$$

\section{Mengukur Karakteristik Habitat Larva Aedes spp.}

Pengukuran karakteristik habitat meliputi jenis kontainer, dan jumlah kontainer positif larva Aedes spp. Pengukuran maya index menggunakan indikator HRI dan BRI. Kedua indikator tersebut dikategorikan menjadi 3 yakni; tinggi, sedang, dan rendah yang membentuk tabel $3 \times 3$ berdasarkan distribusi tertiles. ${ }^{13}$ Kategori maya index dapat dilihat pada Tabel 2, yaitu maya index tinggi jika BRI3/HRI3, BRI3/HRI2, dan BRI2/HRI3; kategori MI sedang jika BRI1/HRI3,
BRI2/HRI2, dan BRI3/HRI1; kategori MI rendah jika BRI1/HRI1, BRI2/HRI1, dan BRI1/HRI2. ${ }^{13,14}$

Kontainer yang diamati dikategorikan menjadi kontainer terkendali/Controllable Containers (CC) dan kontainer bekas/Disposable Containers (DC). Controllable containers adalah tempat yang dapat dikontrol atau dikendalikan oleh manusia. Disposable containers adalah tempat yang tidak dapat dikontrol atau dikendalikan oleh manusia. Untuk mendapatkan indikator HRI dan BRI menggunakan rumus sebagai berikut. ${ }^{13,14}$

$$
\begin{aligned}
\text { HRI } & =\frac{\text { Jumlah Disposable container }(\mathrm{DC})}{\text { Rata }- \text { rata Disposable container }(\mathrm{DC})} \\
\mathrm{BRI} & =\frac{\text { Jumlah Controllab le container }(\mathrm{CC})}{\text { Rata }- \text { rata Controllab le container }(\mathrm{CC})}
\end{aligned}
$$


Tabel 2. Matrik 3x3 Komponen Breeding Risk Indicator (BRI) dan Hygiene Risk Indicotor (HRI) pada Maya Index

\begin{tabular}{ccccc}
\hline & & \multicolumn{3}{c}{ BRI } \\
\cline { 3 - 5 } & Kategori & 1 & 2 & 3 \\
& & (RENDAH) & (SEDANG) & (TINGGI) \\
\hline \multirow{4}{*}{ HRI } & 1 & BRI1/HR1 & BRI2/HRI1 & BRI3/HRI1 \\
& (RENDAH) & (rendah) & (rendah) & (sedang) \\
& 2 & BRI1/HR2 & BRI2/HRI2 & BRI3/HRI2 \\
& (SEDANG) & (rendah) & (sedang) & (tinggi) \\
& 3 & BRI1/HRI3 & BRI2/HRI3 & BRI3/HRI3 \\
& $($ TINGGI) & (sedang) & (tinggi) & (tinggi) \\
\hline
\end{tabular}

Sumber: Dhewantara dan Dinata, Astuti et al. ${ }^{13,14}$

HASIL

\section{Jenis Kontainer}

Jenis kontainer dan kepadatan populasi larva pada 20 kelurahan di Kota Ternate disajikan pada Tabel 3.

Tabel 3. Jenis Kontainer pada 20 Kelurahan di Kota Ternate Bulan Oktober 2016-Februari 2017

\begin{tabular}{|c|c|c|c|c|c|}
\hline No & Jenis kontainer & $\begin{array}{c}\text { Jumlah } \\
\text { kontainer }\end{array}$ & $\begin{array}{c}\text { Kontainer } \\
(\%)\end{array}$ & $\begin{array}{c}\text { Kontainer Postif } \\
\text { larva }\end{array}$ & $\begin{array}{c}\text { Positif larva } \\
(\%)\end{array}$ \\
\hline \multicolumn{2}{|c|}{ Controllable Containers $(C C)$} & \multicolumn{3}{|c|}{79,34} & 94,22 \\
\hline 1 & Bak mandi & 1.774 & 24,41 & 1.524 & 40,68 \\
\hline 2 & BakWC & 579 & 7,97 & 557 & 14,87 \\
\hline 3 & Ember & 1.135 & 15,62 & 275 & 7,34 \\
\hline 4 & Pot bunga & 756 & 10,40 & 0 & 0 \\
\hline 5 & Talang air & 105 & 1,44 & 0 & 0 \\
\hline 6 & Drum plastik & 1.057 & 14,55 & 972 & 25,95 \\
\hline 7 & Sumur & 53 & 0,73 & 0 & 0 \\
\hline 8 & Bak air & 45 & 0,62 & 35 & 0,93 \\
\hline 9 & Tempat makan hewan & 35 & 0,48 & 2 & 0 \\
\hline 10 & Jerigen & 553 & 7,61 & 0 & 0 \\
\hline 11 & Penampung kulkas & 352 & 4,84 & 0 & 0 \\
\hline 12 & Gentong & 275 & 3,78 & 257 & 6,86 \\
\hline 13 & Tempat air wuddu & 95 & 1,31 & 12 & 0,32 \\
\hline \multirow[t]{2}{*}{14} & Dispenser & 453 & 6,23 & 112 & 2,99 \\
\hline & Jumlah & 7.267 & 100 & 3.746 & 100 \\
\hline \multicolumn{2}{|c|}{ Disposable Containers (DC) } & \multicolumn{3}{|c|}{20,66} & 5,78 \\
\hline 1 & Bak Air bekas & 53 & 2,80 & 27 & 11,74 \\
\hline 2 & Kaleng bekas & 573 & 30,29 & 55 & 23,91 \\
\hline 3 & Botol bekas & 375 & 19,82 & 15 & 6,52 \\
\hline 4 & Ban bekas & 57 & 3,01 & 5 & 2,17 \\
\hline 5 & Ember bekas & 355 & 18,76 & 23 & 10 \\
\hline 6 & Toples bekas & 110 & 5,81 & 17 & 7,39 \\
\hline 7 & Gelas bekas & 157 & 8,30 & 12 & 5,22 \\
\hline 8 & Kolam ikan & 12 & 0,63 & 7 & 3,04 \\
\hline 9 & Drum bekas & 75 & 3,96 & 37 & 16,09 \\
\hline 10 & Panci bekas & 35 & 1,85 & 15 & 6,52 \\
\hline 11 & Akuarium bekas & 12 & 0,63 & 5 & 2,17 \\
\hline & Potongan bambu & 21 & 1,11 & 12 & 5,22 \\
\hline \multirow[t]{3}{*}{13} & Tempurung kelapa & 57 & 3,01 & 0 & 0 \\
\hline & Jumlah & 1.892 & 100 & 230 & 100 \\
\hline & Total & 9.159 & 100 & 3.976 & 100 \\
\hline
\end{tabular}


Tabel 3 menunjukkan bahwa jumlah kontainer yang disurvei pada 1.990 rumah di Kota Ternate sebanyak 9.159 kontainer. Kontainer terbanyak adalah CC sebanyak 7.267 (79,34\%), dengan jenis kontainer paling banyak ditemukan adalah bak mandi $(24,41 \%)$. Sedangkan Disposable containers terbanyak adalah jenis kaleng bekas $(30,29 \%)$. Kontainer positif ditemukan larva Ae. aegypti sebanyak
3.976 dengan jenis terbanyak adalah CC yaitu $3.746(94,22 \%)$.

\section{Kepadatan Larva Aedes aegypti}

Hasil pengukuran kepadatan larva CI, HI, dan BI pada 20 kelurahan (Tabel 4) sebesar $43,95 \%$; 84,99\%; dan 228,91\% dengan DF pada kategori tinggi $(\mathrm{DF}=8,7)$.

Tabel 4. Kepadatan larva Ae. aegypti di 20 Kelurahan di Kota Ternate Oktober 2016-Februari 2017

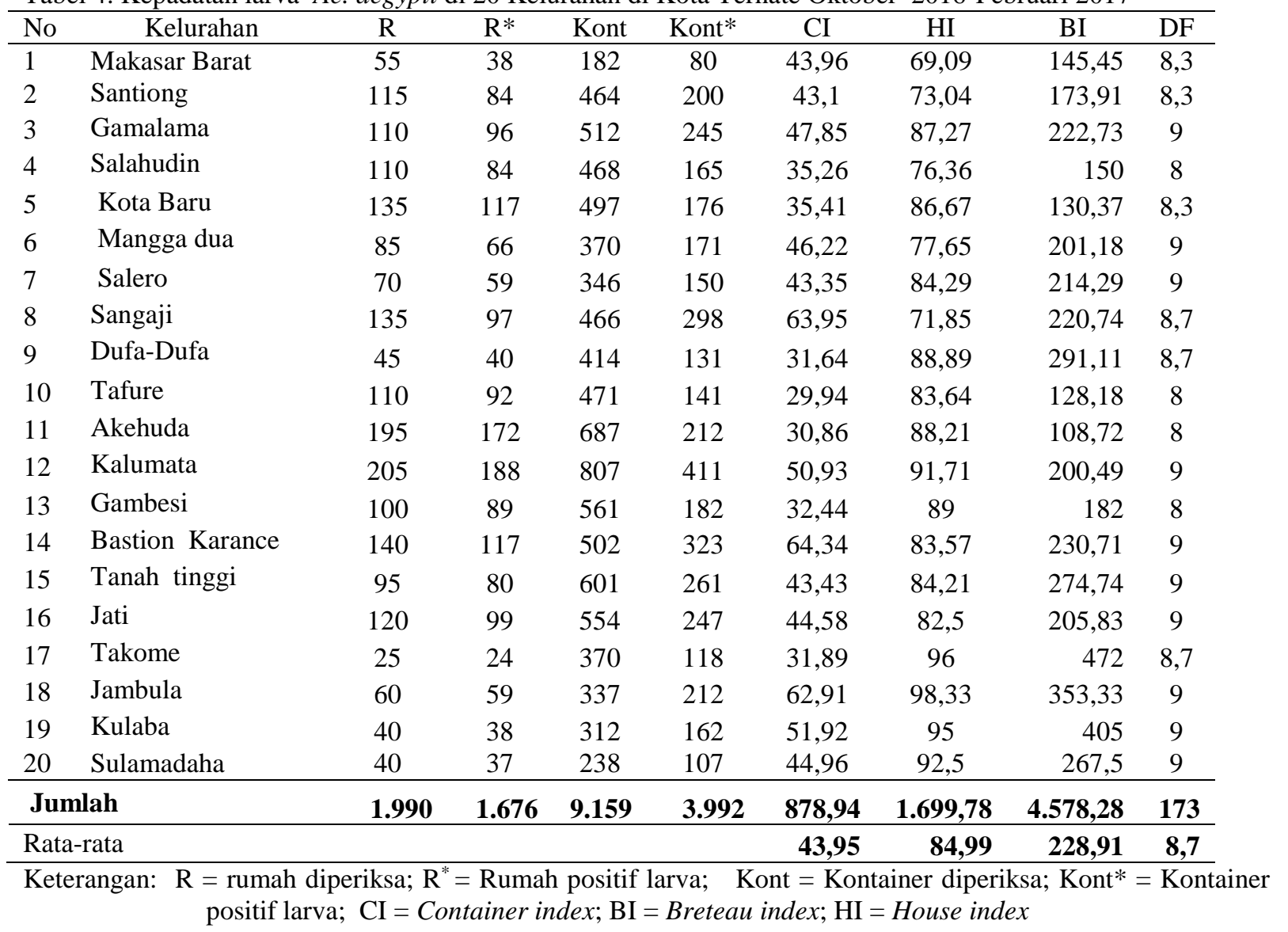

\section{Maya Index}

Status maya index didasarkan pada kebersihan lingkungan (HRI) dan tempat yang berpotensi sebagai tempat perkembangbiakan nyamuk (BRI). Analisis maya index (Tabel 5), menunjukkan bahwa nilai BRI, HRI, dan maya index di Kota Ternate sebagian besar berada pada kategori sedang. Sedangkan nilai BRI, HRI, dan MI kategori rendah kurang dari 10\% dan kategori tinggi kurang dari $20 \%$.

Tabel 5. Persentase Rumah Berdasarkan Kategori Breeding Risk Index (BRI) dan Hygiene Risk Index (HRI) dan Maya Index (MI) pada di Kota Ternate

\begin{tabular}{lcccccc}
\hline \multirow{2}{*}{ Kategori } & \multicolumn{3}{c}{ BRI } & \multicolumn{2}{c}{ HRI } & \multicolumn{2}{c}{ MI } \\
\cline { 2 - 7 } & $\sum \mathrm{rmh}$ & \% rmh & $\sum \mathrm{rmh}$ & \% rmh & $\sum \mathrm{rmh}$ & \% rmh \\
\hline Rendah & 84 & 4,22 & 48 & 2,42 & 111 & 5,58 \\
Sedang & $\mathbf{1 . 5 5 2}$ & $\mathbf{7 7 , 9 9}$ & $\mathbf{1 . 6 5 6}$ & $\mathbf{8 3 , 2 1}$ & $\mathbf{1 . 5 6 5}$ & $\mathbf{7 8 , 6 4}$ \\
Tinggi & 354 & 17,79 & 286 & 14,37 & 314 & 15.78 \\
\hline Total Rumah & 1.990 & 100 & 1.990 & 100 & 1.990 & 100 \\
\hline
\end{tabular}

Keterangan $\sum \mathrm{rmh}=$ Jumlah rumah ; \% $\mathrm{rmh}=$ Persentase rumah 


\section{PEMBAHASAN}

Kontainer

merupakan wadah

penampung air, baik untuk keperluan seharihari maupun penampung air hujan. Jumlah kontainer yang diamati sebanyak 9.159 kontainer, terdiri dari 7.267 kontainer yang dapat dikontrol dan 1.892 kontainer yang tidak dapat dikontrol. Jumlah kontainer positif larva Ae. aegypti sebanyak $43,41 \%$ dari jumlah kontainer yang yang disurvei sebesar 3.976 kontainer. Kontainer tersebut merupakan habitat yang potensial bagi perkembangbiakan nyamuk Ae. aegypti. Faktor lingkungan yang buruk dengan kondisi kontainer yang tidak terawat akan menciptakan habitat perkembangbiakan nyamuk Ae. aegypti, sehingga mempermudah persebaran dan penularan penyakit DBD. ${ }^{15}$

Hasil penelitian Hastuti et al. menunjukkan bahwa controllable container lebih dominan (94,3\%) ditemukan di Tangerang Selatan, dan positif Ae. aegypti. ${ }^{14}$ Hal yang sama juga ditemukan oleh Dewantara dan Dinata di Kota Banjar pada tahun 2012 sebagian besar larva Ae. aegypti ditemukan pada kontainer terkendali (controllable container) yaitu sebesar $94,29 \% .^{13}$

Analisis kepadatan larva Ae. aegypti HI, BI, dan CI di Kota Ternate berada pada kategori tinggi. Menurut Focks dalam Pahlepi et al. menjelaskan bahwa berdasarkan kategori WHO, apabila nilai $\mathrm{HI}$ dan $\mathrm{CI}>5 \%$ dan $\mathrm{BI}>50$ maka daerah tersebut memiliki risiko tinggi terjadinya transmisi DBD. ${ }^{16}$ Nilai CI dan HI Kota Ternate $>5 \%$, dan BI Kota Ternate $>50$, hal ini menunjukkan bahwa Kota Ternate memiliki risiko tinggi terjadinya transmisi DBD. Indikator entomologi seperti HI, BI, CI, dan Angka Bebas Jentik (ABJ) umum digunakan untuk monitoring kepadatan vektor DBD. Breteau Index dan HI pada umumnya digunakan untuk menentukan daerah prioritas pengendalian. Apabila $\mathrm{BI} \geq 20$ dan atau $\mathrm{HI}>5 \%$ maka daerah tersebut dikategorikan peka terhadap DBD dan terinfestasi jentik tinggi. ${ }^{17}$

Tingginya kepadatan larva Ae. aegypti di Kota Ternate karena kebiasaan masyarakat menampung air lebih dari satu minggu dan jarang dibersihkan. Kondisi ini menyebabkan terbentuknya tempat perkembangbiakan bagi nyamuk Ae. aegypti. Menurut Nafida et al. masyarakat yang tidak sempat menguras tempat-tempat penampungan air secara rutin sekali seminggu, sehingga berpotensi sebagai tempat perkembangbiakan nyamuk $A e$. aegypti. ${ }^{18}$ Selanjutnya hasil penelitian di Padukuhan Dero Condong Catur Kabupaten Sleman dilaporkan bahwa larva nyamuk Ae. aegypti banyak ditemukan pada kontainer yang berada di dalam rumah. Kebiasaan masyarakat yang suka menampung air untuk kebutuhan sehari-hari di dalam rumah dalam keadaan terbuka. Hal ini menyebabkan nyamuk Ae. aegypti dengan mudah masuk untuk meletakkan telurnya. Kondisi kontainer yang tidak dikuras dalam waktu satu minggu mengakibatkan telur nyamuk Ae. aegypti yang diletakkan di kontainer dapat melewati siklus (siklus hidup nyamuk Ae. aegypti yang berkisar antara 7-12 hari) secara sempurna sehingga menjadi nyamuk dewasa. ${ }^{19}$ Hasil penelitian Astuti dan Lustiani tahun 2018 di Sekolah Dasar Wilayah Kecamatan Kasihan, Bantul, Yogyakarta, menunjukkan pencahayaan yang sangat kurang berpotensi sebagai tempat perkembangbiakan larva Aedes spp. ${ }^{20}$

Tingginya tingkat kepadatan larva $A e$. aegypti akibat dari banyaknya penampungan air (kontainer) yang berpotensi menjadi tempat perkembangbiakan Ae. aegypti. Selain itu tidak jalannya program pengendalian sarang nyamuk secara rutin. Kegiatan pemberatasan sarang nyamuk melalui program PSN merupakan kegiatan Dinas Kesehatan Kota Ternate. Kegiatan PSN sebagai upaya untuk menekan penyebaran penyakit DBD di Kota Ternate. Program yang telah dicanangkan tidak sejalan dengan implementasi program tersebut di lapangan. Hal yang sama juga dilaporkan oleh Widiarti et al. di Provinsi Jawa Tengah menyebutkan bahwa tingginya kasus DBD di Provinsi Jawa Tengah karena adanya gap antara kebijakan dengan pelaksanaan program di daerah kajian. Program yang dicanangkan tidak optimal dijalankan seperti program PSN yang tidak berjalan dengan optimal, larvasidasi hanya dilakukan pada saat ada KLB saja dan pada 
wilayah endemis saja serta fogging dilakukan hanya dalam satu siklus kehidupan vektor saja. ${ }^{21}$

Menurut WHO, indikator adanya ancaman wabah DBD adalah apabila terdapat daerah dengan DF $>5$, ini berarti akan terjadinya transmisi penyakit DBD, sedangkan apabila DF 1-5, maka terjadi transmisi penyakit DBD dianggap rendah hingga sedang. ${ }^{22}$ Kota Ternate memiliki $\mathrm{DF} \geq 8$ (DF $=8,7)$, kondisi ini memungkinkan terjadinya transmisi penyakit DBD yang tinggi. Hasil yang sama dilaporkan oleh Phallepi et al. di Kota Palembang pada kategori kepadatan tinggi dengan $\mathrm{DF}=8$ berpotensi untuk terjadi transmisi DBD. ${ }^{16}$ Hasil tersebut lebih tinggi bila dibandingkan dengan penelitian yang dilakukan di Kelurahan Surgi Mufti Banjarmasin dan Kota Semarang yaitu $\mathrm{DF}=5$ dan $\mathrm{DF}=6$, yang hanya berada pada kategori sedang dan tinggi untuk berpotensi terjadinya risiko penularan penyakit DBD. ${ }^{23}$ Sementara di Kelurahan Labuh Baru Timur nilai skala DF berada pada nilai 3 dan 5 yaitu berada pada kategori sedang. ${ }^{24}$

Penelitian di Kota Ternate mengungkapkan bahwa setiap rumah yang dijadikan sampel memiliki tempat perkembangbiakan nyamuk (BRI) dan aspek kebersihan rumah (HRI) masih berada pada kategori sedang. Status maya index berdasarkan kategori BRI dan HRI menunjukkan bahwa sebagian besar rumah di Kota Ternate termasuk dalam kelompok kategori sedang. Hal ini perlu adanya perhatian masyarakat terhadap upayaupaya Pengendalian Sarang Nyamuk (PSN), khususnya pada tempat-tempat penampungan air yang berada dalam rumah. Keberadaan tempat perkembangbiakan nyamuk Ae. aegypti (BRI) dan kebersihan lingkungan (HRI) berpengaruh pada tingkat kepadatan nyamuk Ae. aegypti di lingkungan pemukiman. Semakin banyak kontainer yang ada di sekitar lingkungan rumah semakin besar risiko menjadi habitat perkembangbiakan nyamuk sebagai sumber penularan DBD.

Berdasarkan analisis maya index sebagian masyarakat Kota Ternate berada pada tingkat risiko kategori sedang $(78,64 \%)$. Kondisi ini menunjukkan bahwa Kota Ternate berpeluang terjadinya penularan penyakit DBD. Menurut Novita et al. bahwa maya index kategori sedang dan tinggi meningkatkan terjadinya penularan virus Dengue di suatu wilayah. ${ }^{25}$ Beberapa penelitian yang menghasilkan maya index dalam kategori sedang yaitu penelitian Taslisia et al. di Desa Salido Kecamatan IV Jurai Kabupaten Pesisir Selatan maya index $=93 \%$ dan penelitian Prasetyowati et al. di Kota Bandung maya index $=77,74 \% .^{26}$

Upaya pengendalian vektor dapat dilakukan dengan melakukan kegiatan PSN dengan melibatkan instansi terkait dan masyarakat. Menurut Astuti et al. bahwa index kepadatan dapat dikendalikan dengan berbagai upaya seperti melakukan manajemen pengelolaan sampah, peningkatan kegiatan PSN. Kegiatan ini harus dilakukan bersamasama lintas sektor dan pemberdayaan masyarakat dengan mengoptimalkan kegiatan promosi kesehatan ke masyarakat serta menggandeng pemangku wilayah (walikota, camat, lurah) agar kegiatan pengendalian

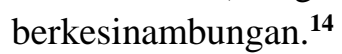

\section{KESIMPULAN}

Status maya index dan kondisi sanitasi lingkungan di Kota Ternate berada pada kategori sedang. Kepadatan larva Ae. aegypti di Kota Ternate berada pada kategori tinggi artinya Kota Ternate memiliki risiko penularan tinggi terhadap penyebaran penyakit DBD.

\section{SARAN}

Perlu dilakukan pengendalian Ae. aegypti melalui upaya pemeriksaan jentik berkala terutama pada tempat-tempat penampung air di dalam rumah yang terkendali, serta memodifikasi dan manipulasi lingkungan dengan menerapkan prinsip 3R untuk mengurangi kontainer yang tidak terkontrol.

\section{UCAPAN TERIMA KASIH}

Ucapan terima kasih kepada Dinas Kesehatan Kota Ternate dan Sekolah Tinggi Ilmu Kesehatan Kota Ternate serta masyarakat pada 20 Kelurahan di Kota Ternate atas bantuan 
dan kerja samanya selama penelitiannya berlangsung.

\section{DAFTAR PUSTAKA}

1. Pusat Data dan Informasi Kementrian Kesehatan RI. Situasi DBD di Indonesia. Jakarta;2016. ISNN. 2442 7659 .

2. Dinas Kesehatan Kota Ternate. Profil kesehatan Kota Ternate. Ternate; 2017.

3. Azlina A, Adrial, Anas E. Hubungan tindakan pemberantasan sarang nyamuk dengan keberadaan larva vektor DBD di Kelurahan Lubuk Buaya. Jurnal Kesehatan Andalas.2016;5(1):221-7. doi: 10.25077/jka.v5.i1.p\%25p.2016.

4. Kementerian Kesehatan RI. Pedoman pengendalian Demam Berdarah Dengue di Indonesia. Jakarta: Dirjen Pencegahan dan Pengendalian Penyakit; 2017.

5. Fatmawati T, Ngabekti S. dan Priyono B. Distribusi dan kelimpahan populasi Aedes spp. di Kelurahan Sukorejo Gunung Pati Semarang berdasarkan pelatakan ovitrap. Unnes J. Life Sci. 2014;3(2):1308 .

6. WHO. Panduan lengkap pencegahan dan pengendalian dengue dan demam berdarah dengue. Jakarta: EGC; 2005.

7. Soedarto W. Demam Berdarah Dengue (Dengue Haemorrhagic Fever). Jakarta: Sagung Seto; 2012.

8. Sulistyorini E, Hadi UK, Soviana S. Faktor entomologi terhadap keberadaan jentik Aedes sp. pada kasus DDBD tertinggi dan terendah di Kota Bogor. Jurnal MKMI.2016;12(3):137-47.

9. Satoto TBT, Umniyati SR, Astuti FD, Wijayanti N, Gavotte L, Devaux C, et al. Assesment of vertical dengue virus transmission in Ae. aegypti and serotype prevalence in Bantul,Indonesia. Asian Pac J Trop.2014;4(2):S563-8. doi: 10.1016/S2222-1808(14)60677-0.

10. Taslisia T, Rusjdi S R, Hasmiwati. Survei entomologi, maya indeks, dan status kerentanan larva nyamuk Aedes aegypti terhadap temephos. J. Kesehatan Andalas. 2018;7(1):33-41.

11. Kementerian Kesehatan RI. Pedoman pengendalian demam berdarah dengue di Indonesia. Jakarta: Kementerian Kesehatan RI.Dit.Jen.PP \&PL;2015.
12. Lestari E, Sianturi CLJ, Hestiningsih R, Wuryanto MA. Kepadatan jentik vektor Demam Berdarah Dengue (DBD) Aedes sp. di daerah endemis, sporadis dan potensial Kota Semarang, Provinsi Jawa Tengah. BALABA. 2014;10(2):71-6.

13. Dhewantara $\mathrm{P}$, Dinata $\mathrm{A}$. Analisis risiko dengue berbasis maya index pada rumah penderita DBD di Kota Banjar tahun 2012. BALABA 2015;11(1):1-8.

14. Astuti EP, Prasetyowati H, Ginanjar A. Risiko penularan demam berdarah dengue berdasarkan maya indeks dan indeks entomologi di Kota Tangerang Selatan, Banten. Media Litbangkes.2016;26(4):211-8.

15. Sukendra D., Shidqon M A. Gambaran perilaku menggigit nyamuk Culex sp. sebagai vektor penyakit filariasis Wuchereria bancrofti. Pena Medika J. Kesehatan, 2016;6(1):19-3.

16. Pahlepi R.I, Soviana S, Elok Budi Retnani E.B. Kepadatan dan karakteristik habitat larva Aedes spp. di sekolah dasar daerah endemis DBD Kota Palembang. SPIRAKEL. 2017;9(2): 68-78.

17. Badriah S, Hidayah N. Hubungan antara tempat perindukan nyamuk Aedes aegypti dengan kasus demam berdarah dengue di Kelurahan Penajam Kecamatan Penajam Kabupaten Penajam Paser Utara. J.Trop Pharm Chem. (Indonesia). 2011;1(2):153-60.

18. Nadifah F, Muhajir NF, Arisandi D, Lobo OMD. Identifikasi larva nyamuk pada tempat penampungan air di Padukuhan Dero Condong Catur Kabupaten Sleman. JKMA. 2016.;10(2): 172-8.

19. Santoso, Taviv Y, Mayasari R, Margarethy I, Wempi DSP. I Gede, Marini. The relationship between container characteristics and Aedes aegypti larvae on dengue hemorrhagic fever outbreak: a case study in Ogan Komering Ulu District. J.Vektor Penyakit. 2018;12(1):9-18.

20. Astuti P, Lustiyati ED. Hubungan kondisi lingkungan fisik terhadap tingkat kepadatan larva Aedes sp. di sekolah dasar wilayah Kecamatan Kasihan, Bantul, DI Yogyakarta. Jurnal Ilmu Kesehatan. 2018;9(3):216-25. doi: 10.26553/jikm.v9i3.314.

21. Widiarti, Setiyaningsih, R., Pratamawati, D.A. Implementasi pengendalian vektor DBD di Provinsi Jawa Tengah. J Ekol Kes. 2018;17(1): 20-30. 
22. World Health Organization. Panduan lengkap pencegahan dan pengendalian dengue dan demam berdarah dengue. Jakarta: EGC; 2005.1101.

23. Khairunisa U, Wahyuningsih NE, Hapsari. Kepadatan jentik nyamuk Aedes sp. (house index) sebagai indikator surveilans vektor demam berdarah dengue di Kota Semarang. Jurnal Kesehatan Masyarakat. 2017; 5(5):90610 .

24. Maryanti E, Lesmana S.D, Triguna D, Plymoth M, Harmas W, Delly, Afiata, Mislindawati. Maya index dan kepadatan larva Aedes aegypti di daerah endemis demam berdarah dengue Kelurahan Labuh Baru Timur Kecamatan Payung Sekaki Kota Pekanbaru. JIK. 2018;12(1):19-24.
25. Nofita E, Hasmiwati, Rusdji SR, Irawati N. Analysis of indicators entomology Aedes aegypti in endemic areas of dengue fever in Padang, West Sumatra, Indonesia. Int J. Mosq Res.2017;4(2):57-9.

26. Prasetyowati H, Astuti E.P, Hendri J, Fuadzy H. Risiko penularan DBD berdasarkan maya index dan key container pada rumah tangga kasus dan kontrol di Kota Bandung. BALABA. 2018;14(2):181-90. 
BALABA Vol. 15 No. 2, Desember 2019: 133-142 